Author: Gabrina Pounds

Title:

The Values of Trees and Woodland: A Discourse-based Cross-disciplinary Perspective on Integrating 'Revealed' Evaluations of Nature into Environmental Agendas

\title{
Institutional address
}

School of Politics, Philosophy, Language and Communication Studies

Faculty of Arts and Humanities

University of East Anglia

Norwich Research Park

Norwich NR4 7TJ

UK

Tel: 0044-(0)1603-593621

E-mail: g.pounds@uea.ac.uk

Private address

22 Greenways

Norwich NR4 6PE

UK

Tel: 0044-(0)1603-451323 


\title{
The Values of Trees and Woodland: A Discourse-based Cross-disciplinary Perspective on Integrating 'Revealed' Evaluations of Nature into Environmental Agendas
}

\begin{abstract}
Discourse analysis has been widely applied to the study of environmental communication, highlighting how language is used to reflect and affect our attitudes towards the natural world. The potential of discourse analysis to 'reveal' the values that people attribute to nature has recently been recognized in the context of environmental debates. This paper takes a new cross-disciplinary approach to the analysis of evaluation, combining a discourse approach (specifically Appraisal analysis, Martin and White, 2005) and insights from environmental philosophy and environmental policy to address the following main questions:

1) Which values of nature may be embedded in discourse about nature?

2) To what extent are these values represented in people's narratives about trees and woodland in the UK?

3) What are the implications of the findings for the critical analysis of evaluative discourse?
\end{abstract}

4) What are the implications of the findings for environmental organizations? The analysis is applied to a sample of 514 woodland narratives collected by the UK charitable environmental organization Woodland Trust in 2016. The study highlights new critical perspectives that may be gained from the analysis of evaluative discourse and the importance of considering and fostering people's affective relationship with the natural world in building a strong basis for environmental action.

\section{Key words}

Discourse; evaluation; appraisal; values of nature; environmental philosophy; environmental policy; woodland; trees; stories; environmental organizations. 


\section{Introduction}

Within the wider umbrella term of ecolinguistics, discourse analysis has been extensively applied to the study of environmental communication to highlight how language is, and may be, used to reflect and affect our attitudes towards the natural world and its values. Stibbe (2015, p.1) argues, for example, that 'The language of advertising can encourage us to desire unnecessary and environmentally damaging products, while nature writing can inspire respect for the natural world. How we think has an influence on how we act, so language can inspire us to destroy or protect the ecosystems that life depends on'.

From an environmental perspective, the values of nature have been widely debated with reference to the controversial concept of natural capital (e.g. Cooper et al., 2016; Read and Scott Cato, 2014; Turnpenny and Russel, 2017). This debate concerns the practical and ethical validity of assigning monetary value to natural 'resources' as a means to ensure their recognition and protection. The controversy centres on the notion of 'ecosystem service' and the underlying assumptions that a) the value of nature resides purely in the benefits that it may offer humanity and b) that such benefits may be estimated. It is generally acknowledged that the non-material values of nature (for example, its aesthetic or cultural values) are hard to estimate and that formal cost-benefit analysis is not appropriate.

Mindful of these difficulties, environmental government bodies (e.g. the UK National Ecosystem Assessment) have applied new social sciences and humanities-inspired assessment methodologies, including survey approaches (known as 'stated preference methods') and 'deliberative approaches' (in which values are established through dialogue and consensus) to obtain a wider understanding of the non-material values of nature (Bateman et al., 2010).

More recently, a further approach ('revealed preference approach', Bateman et al., 2010), has been advocated and applied, involving the collection and analysis of visible 
evidence of non-material use of natural assets, including discourse and images. However, discourse analysis of this material has so far been limited to thematic analysis of narratives that were framed by the specific pre-set range of the evaluative categories investigated. Cooper (2019, p. 244 and p. 261) proposes that further insight may be gained from a more detailed linguistic analysis.

In this paper, I take up Cooper's invitation and develop a new cross-disciplinary approach to the analysis of evaluation, combining a discourse approach (specifically Appraisal analysis, Martin and White, 2005) and insights from environmental philosophy (e.g. Callicott, 1989; Taylor, 1986) to address the following main questions:

1) Which values of nature may be embedded in discourse about nature?

2) To what extent are these values represented in the narratives of people who feel very positive about trees and woodland in the UK?

3) What are the implications of the findings for the critical analysis of evaluative discourse?

4) What are the implications of the findings for environmental organizations?The analysis is based on a sample of 514 woodland narratives collected by the UK charitable environmental organization Woodland Trust (WT) ${ }^{1}$ in 2016 . WT's main aim is to promote the value of trees and woodland so that they may be preserved now and in the future. The narratives were collected with the specific purpose of translating people's concerns and experiences with trees and woodland into a new Charter for Trees, Woods and People ${ }^{2}$ (henceforth the Charter).

Sections 2 and 3 address question 1, providing an overview of the values that may be ascribed to nature from a philosophical and an environmental policy perspective,

\footnotetext{
${ }^{1}$ The Woodland Trust, Kempton Way, Grantham, Lincolnshire NG316LL. Woodlandtrust.org.uk

2 The Charter was commissioned by WT and designed, written out and painted by Patricia Lovett, 2017. It may be viewed at https://treecharter.uk
} 
respectively. Sections 4 to 6 address question 2, focusing on some of the attempts made so far to capture ordinary people's views of nature and its values (section 4.), clarifying WT's aims and objectives with reference to the narratives collected (section 5) and outlining and illustrating the discourse analytical process developed for this study (section 6). The final sections address questions 3 and 4, discussing the theoretical and methodological contributions of the study and its implications for environmental policies.

\section{Values of Nature: Philosophical Perspectives}

The values ascribed to nature from an environmental philosophy perspective may be of three main kinds: intrinsic objective, intrinsic subjective and instrumental (Sandler, 2012):

Intrinsic objective values are not valuer-dependent and are non-conditional. They are discovered rather than created by humans. Their intrinsic objectivity may be perceived as residing in either nature's distinct natural-historical evolution (i.e. nature's independence from human design and control, Katz, 1992, and from the human evolutionary process, Rolston, 1986) or in nature's inherent worth (i.e. nature possessing a 'good' of its own, independently from effects on other entities, Sterba, 2001; Taylor, 1986).

Intrinsic subjective values, on the other hand, are valuer-dependent and conditional (Callicott, 1986; Elliot, 1992) but according to reason-oriented and arguable criteria, including: complexity, diversity, spiritual significance, wilderness, beauty, wondrousness.

Buijs et al. (2011, p. 332) similarly distinguish between biocentric and anthropocentric values of nature, with the former being independent from human design and benefit and the latter entailing a functional social representation dependent on human appreciation. 
Like subjective intrinsic values, instrumental values are valuer-dependent and conditional, but their conditionality is based on more utilitarian, transitory and derivative appreciation of nature, including, for example, economic, medicinal or recreational values.

\section{Values of Nature: Environmental Policy Perspectives}

Environmental policy makers take an essentially instrumental perspective of natural values, as evidenced by the adoption of the concept of ecosystem service, but have, over time, included some subjective intrinsic values in their overall classifications, attempting to price 'goods and services' that do not have a market value. In the Millennium Ecosystem Assessment $^{3}$ (2001-2005), for example, ecosystem services are grouped under three main types of direct benefits:

a) provisioning services: products obtained from ecosystems, e.g. food and fibre.

b) regulating services: benefits obtained from regulation of ecosystem processes, e.g. climate regulation and water purification.

c) cultural services: nonmaterial (or non-traded ecosystem services) benefits obtained from ecosystems, e.g. recreation and aesthetic values.

Group c) is clearly more open-ended than groups a) and b). In the chapter dedicated to 'cultural services and amenities', de Groot and Ramakrishnan (2005, pp. 457-474) further classify group c) as including:

- cultural identity (that is, the current cultural linkage between humans and their environments).

- heritage values ('memories' in the landscape from past cultural ties).

- spiritual services (sacred, religious or other forms of spiritual inspiration derived from ecosystems).

\footnotetext{
${ }^{3}$ Produced by the United Nations between 2001 and 2005, attempting to qualify all the services provided to humans by nature.
} 
- inspiration (the use of natural motives or artefacts in arts, folklore, and so on)

- aesthetic appreciation of natural and cultivated landscapes.

- recreation and tourism.

In the Common International Classification of Ecosystem Services (CICES) project (version 4.3, 2013), the European Environment Agency, re-conceptualizes cultural services in terms of 'interactions' rather than services, to highlight their non-instrumentality.

Whilst observing the ultimate conditionality (on human benefit) of the values attributed to nature (as further evidenced, for example, in the documents produced by the UK Department of for Environment, Food \& Rural Affairs, DEFRA, 2015), Cooper (2016, p. 220) points out that a distinction is made, in these and similar documents, between various types of human benefit by the degree to which they are linked to material outcomes: from more abstract and intangible benefits (e.g. emotive impact or immersive/ sensorial experience) to more basic practical benefits.

In this context, Cooper (2016, p. 220) also highlights the distinction, often made in aesthetics studies (e.g. Carlson, 2010), between a narrow concept of aesthetic valuing, in which beauty is appreciated as a purely visual (or 'photographic') and static quality and a wider immersive, multisensory aesthetic appreciation, in which the human subject is affected by and immersed in nature. The latter is further defined by Berleant (2013) as 'aesthetics of engagement'. Cooper (2016, p. 222) suggests that, at its most engaging, aesthetic appreciation may become so object (nature)-centred that its valuer-dependency is backgrounded. In these cases, the natural entity appears to inspire in the human viewer a sense of its intrinsic beauty, which may be experienced by the viewer as an expression of its intrinsic objective value.

\section{Values of Nature: Ordinary People's Perspectives}


Ultimately, the success of conservation policies is dependent on some alignment between institutional understanding of environmental values and people's appreciation of the natural environment. As mentioned in section 1, revealed preference methods (Bateman et al., 2010) have recently been applied to record visible evidence of non-material, particularly cultural, appreciations of landscape. One example is a study incorporating the content analysis of people's narratives about the sea (Kenter et al., 2016). A further example is a qualitative social-empirical study of how residents of a biosphere reserve in south-western Germany (the Swabian Alb) perceive, understand and mentally structure their biophysical surroundings, as revealed in their short stories (Bieling, 2016).

All these studies confirm the importance ascribed by the respondents to the nonmaterial, cultural values of nature. However, this is not particularly surprising, considering that these values were strongly represented in the range of options that respondents were asked to choose from. The study presented here is different in two main ways: Firstly, the participants were less constrained in their responses as they were just generally invited to supply stories about 'what trees and woodland mean to them'. Secondly, a finer, discoursedriven analysis was used, to 'extract' the values of nature expressed in the stories, than the general thematic analyses employed in previous research. The data selection criteria and analytical approach are outlined in sections 5 and 6 respectively.

\section{Tree Stories and the Charter of Trees, Woods and People}

In 2015, over seventy organisations responded to WT's call to join them in supporting the drafting of the Charter. As part of this initiative, WT appealed to the readers of its main publications (Leaf and Broadleaf) to submit a story 'to help us understand what the people in the UK want and need from the UK's trees'. The wording used on the printed and online version of the story submission form invited readers to 'Add your voice and help us create the 
Charter ${ }^{4}$. You could tell us about a tree that is special to you, an experience you've had in the woods or share your thoughts about how trees and woods make you feel. It can be a short memory of a quick anecdote, or something longer'.

The stories were used by WT to translate the respondents' concerns and experiences with trees and woodland into 10 Principles in the new Charter, which was launched on 6th November 2017, the 800th anniversary of the historic 1217 Charter of the Forest ${ }^{5}$. The new Charter does not have legislative status but serves as an important reference point for UK environmental policy makers.

The 514 stories analysed for this study comprise the sample sent to the WT publications, anonymised versions of which were made available to me by WT in three sets for ease of reference ${ }^{6}$. Further 'stories' were collected by WT at specific events or through social media over the year, directly or through the mediation of the supporting organizations, totalling over 60,000 . However, the invitation for these 'stories' was worded in diverse ways and issued in various contexts, resulting in responses provided in many alternative formats, sometimes very short and, overall, less representative of wider views of trees and woodland. The stories analysed are mostly under 100 words each ( 72 words on average $)^{7}$ for a total of 37,507 words. From their content, it is possible to tell that they were contributed by both women and men and are representative of a relatively wide age range (from children to elderly people).

Although wider ranging in their scope than the stories collected in previous studies, the WT stories are still subject to a number of contextual constraints, which need to be

\footnotetext{
${ }^{4}$ Information about the Charter and its aims was made available to readers in the publications. In the Winter publication of Leaf 2017 , for example, readers were told that 'they [the stories] will provide the inspiration and contents for the new Charter'.

${ }^{5}$ The Charter of the Forest was originally sealed in England in 1217 by King Henry III, acting under the regency of William Marshall, 1 st Earl of Pembroke to re-establish for free men rights of access to the royal forest that had been eroded by William the Conqueror and his heirs. It was in many ways a companion document to Magna Carta.

${ }^{6}$ The contributors had supplied their stories with the understanding that they would be used by WT and their collaborators to produce the Charter and related research. My collaboration with WT on the analysis of the stories for the research presented here was officially endorsed by the Trust in an agreement signed on 22-12-2018.

${ }^{7}$ Ranging from 35 to over 300 words. Two of the stories are in poetry form.
} 
accounted for. In particular, the story tellers were all WT members. Although this includes over 250,000 people, they all share a very positive attitude towards trees and woodland, are likely to have had more engagement with trees than the average population, either in their lives or as members of the organizations, and are mostly well-educated, white and middle class. Moreover, WT's original suggestion to include mention of a 'special' tree, 'experience', 'thoughts about how trees and woods make you feel' and 'memory' or 'anecdote' would have influenced the story tellers to focus more on the non-material than the instrumental values of trees. Because of this bias, however, analysis of this material can provide a useful insight into the human experiences that produce a positive attitude to nature.

\section{Analytical Approach}

In order to explore how values of nature are embedded in discourse, it is useful to consider the linguistic evaluative patterns that typically express speakers or writers' attitudinal meanings. The range and functions of such expressions has been extensively investigated by scholars adopting a Systemic Functional Linguistic approach to the analysis of the interpersonal and attitudinal function of language (Halliday and Matthiessen, 2004), particularly through applications of the Appraisal framework, as proposed by Martin and White (2005).

Within this framework, a distinction is made between evaluation of things and events (APPRECIATION: the concert was superb), evaluation of people (JUDGEMENT: the violin player is extremely talented) and expression of feelings (AFFECT: I/they loved the concert). All three evaluative dimensions may play a role in environmental discourse in that stakeholders may express their views and feelings on entities in the natural world, i.e. particular conservation activities and strategies, and/or the individuals or organizations that subscribe, or not, to their positions. 
To the extent that values, in the WT stories, are ascribed to trees and woodland, APPRECIATION would be expected to play a key role. Within the Appraisal model (Martin and White, 2005, p. 56), values of APPRECIATION are subcategorized as shown in Table 1.

\section{[TABLE 1 ABOUT HERE]}

Given the invitation to consider 'what trees and woodland mean to you' (my italics), values of AFFECT may also be significant, particularly on the 'un/happiness' dimension, including references to 'dispositions' such as be fond of or love (Martin and White, 2005, p. 49). A dimension of AFFECT is, however, also included within the categorization of APPRECIATION, specifically APPRECIATION arising from emotive impact under the category of REACTION/IMPACT (see Table 1). Martin and White (2005, pp. 61-62) further distinguish between: 'evaluation that has been directly inscribed in discourse through the use of evaluative lexis' (as exemplified in Table 1) and 'invoked' or implied evaluation, conveyed through the 'selection of ideational meaning, even in the absence of attitudinal lexis'.

Invoked or implied evaluation may be expressed through the use of suggestive figurative language (e.g. listening to the concert felt like being awash with music) ${ }^{8}$ or through specific representations of participants and events. In these cases, more than one attitudinal category may be implicated. She went to the concert twice, for example, may imply that she loved the concert (AFFECT) but also that the concert was excellent (APPRECIATION). Martin and White (2005, p. 63) argue that 'the inscriptions act as sign-posts...telling us how to interpret 'the ideational selections that surround them'. This context- and register-dependency of evaluation, has been highlighted in most studies and theoretical discussions on the topic (noticeably, Huston and Thompson, 1999 and Thompson and Alba-Juez, 2014). Martin and White's framework, which was initially meant to capture aesthetic evaluations in particular,

\footnotetext{
${ }^{8}$ The examples in this section are mine
} 
has been extensively adapted to be used in other contexts, further highlighting the permeability of the evaluative dimensions.

In order to identify the values of nature expressed in the tree narratives, it was necessary to integrate the potential conceptualizations of values of nature (as surveyed in sections 2 and 3) with the appraisal patterns expressed in the stories. This integration was achieved through a recursive inductive and deductive process of analysis over a number of stages. Each analytical stage produced a new set of findings, which was used as the basis for the next stage. The process and the relevant sets of findings are presented in the following subsections.

\subsection{Identification of the Main Values}

Firstly, the narratives were examined to obtain an initial overview of which of the values presented in sections 2 and 3 were represented. This revealed that both intrinsic (objective and subjective) as well as instrumental values were appealed to in the narratives, more or less explicitly. References to intrinsic objective values included expressions such as:

(1) They are a living presence in their own right (Set 3/150),

Intrinsic subjective values were represented through the story-tellers' references to their emotive and sensorial engagement with and aesthetic appreciation of woodland as in:

(2) I have loved trees all my life (Set1/113)

(3) All trees smell good (Set 1/37)

(4) They look great in Autumn colours and the winter snow for great photos (Set 2/53)

Regarding aesthetic appreciation, a distinction could be made between appreciations of 'decorative beauty' (as in example (4)) and more immersive appreciations of beauty of the type that Berleant (2013) would consider 'aesthetic engagement' (see section 3), as in: 
(5) I've always loved walking along them and seeing the different types of trees and the way the strong roots interweave with the soil. It's beautiful (Set 2/154).

As argued at the end of section 3., this deeper aesthetic engagement amounts, for some, to an expression of intrinsic objective value. In the context of the tree narratives, it appears to convey a more intensive emotive immersion in nature than mere appreciation of its 'decorative beauty' but still, arguably, as an expression of humans' subjective involvement with woodland rather than recognition of its essential worth.

Regarding emotive engagement, it was difficult to make a clear distinction between emotion (as in example (2)), pleasure, caring and awe of a quasi-spiritual nature, which may be all subsumed under subjective affect and, often be overlapping. In the following examples, the relevant expressions are underlined:

(6) Living by Alexander Park in Hastings, the joys from childhood right through to now having the pleasure of the mature trees in all seasons. (Set 2/161)

(7) At the time I thought that only fairies could live in this enchanted spot and that they had planted the pretty little flowers. Whenever I see silver birch it brings a smile to my face (Set 2/127)

(8) If I had one wish it would be to be able to draw trees so lifelike in their variety that absolutely no-one would ever be able to fell a tree without feeling a searing wound across their body. (Set 3/12)

(9) Trees provide a spiritual connection to the world we live in (Set 3/28)

Instrumental values were represented through the story-tellers' references to the environmental, health, recreational, socio-cultural, scientific-educational and material benefits to be gained from woodland, as in:

(10) They help protect our environment (Set 1/127) 
(11) Individual trees... induce a state of calm, of perspective, and of wellbeing (Set

(12) .... are fun to play in (Set 1/48)

(13) ...they're an asset to our heritage (Set1/55)

(14) ... [they are] invaluable teaching resource (Set 1/96)

(15) They provide beautiful furniture (Set 1/55)

\subsection{Identification of Relevant Appraisal Patterns}

The second stage of the analytical process involved observing the Appraisal patterns used to express the main values in the narratives. This, in turn, provided further means to distinguish between the values with more precision. The first observation concerns the expression of intrinsic value. It was noticed that, in the narratives, the intrinsic values of trees and woodland may be expressed through explicit APPRECIATION of their uniqueness and essential properties (Valuation in Table 1), as in example (1) above, or more implicitly as in:

(16) Without trees the world will lose one of its dimensions (Set 1/1).

References to particular human-like qualities of trees and to their agency also imply their unique and special status as in:

(17) They [trees] look so different and give you the feeling of being alive and free.

(Set 1/136)

(18) I know as I spend time walking in their presence they send me their thanks??

[Set 2/38]

(19) It amazed me the strength of that branch a testament of a trees ability to weather any storm $($ Set $2 / 82)$ 
It is worth noticing, however, that, in the stories, agency-attribution to trees is not, in itself, implying intrinsic value attribution. In expressions such as:

(20) They also provide us with oxygen and absorb carbon dioxide which is necessary for our survival (Set 3/3)

trees are given grammatical agency, but this does not amount to the human-like agency expressed in examples (17-19). Conversely, grammatical non-agentivity (e.g. attribution in relational processes, as in example (1), may express intrinsic value.

In some of the expressions in which trees are personified, positive APPRECIATION appears to be replaced by positive JUDGEMENT. Within the Appraisal system, values of JUDGEMENT are typically ascribed to people, rather than things and events, and include assessments of people's social and ethical conduct (Normality, Capacity, Tenacity, Veracity and Property), as illustrated in Table 2.

\section{[TABLE 2 ABOUT HERE]}

One can see that the qualities alive and free in example (17) convey an explicit JUDGEMENT of Vitality that falls somewhere between Normality and Capacity. Send me their thanks in example (18) implies a JUDGEMENT of Propriety, whilst strength of that branch and a trees [sic] ability to weather any storm in example (19) implies a JUDGEMENT of Tenacity.

Subjective intrinsic values of emotive engagement (as illustrated in examples (6-9), may be expressed through APPRECIATION/Emotive impact, as in:

(21) Ancient trees, some of which have been growing for hundreds of years, are timeless and have an almost magical attraction. (Set 3/26)

but are more often conveyed through expression of AFFECT, as exemplified in examples (69). These expressions of AFFECT may also include negative emotions engendered by the 
actual or potential destruction of trees and woodland, still conveying the story-tellers' emotive attachment to trees as in:

(22) I hope we never lose them it would be a tragedy. (Set 3/69)

A particular type of emotive engagement was also found in the story tellers' references to positive or significant memories of people and events, amounting to expressions of affectively remembered experience, shaping their identity as in:

(23) I have fond memories of the many elm trees in Crouch End, Hornsey, where I spent the first 29 years of my life. (Set 2/42)

Expressions of sensorial pleasure are also emotive in nature, but refer more specifically to the story-tellers' positive sensorial experiences in woodland, typically expressed through APPRECIATION, which may be conveyed explicitly as in:

(24) All trees smell good (Set 1/37)

or implicitly by references to the sensory effects on the experiencer as in:

(25) The fresh crisp aroma wafts over you as you enter natures home and the canopy (Set 2/54)

As noted in section 6.1, aesthetic values may be expressed through straight forward aesthetic appreciation of trees, as in example (4), or aesthetic appreciation that is combined with more immersive expression of affect, as in example (5).

Expressions of instrumental value essentially amount to more or less explicit APPRECIATION of the tangible benefits to be derived from trees and woodland. These benefits (environmental, health, recreational, socio-cultural, scientific-educational and material) are mostly equated with Valuations of specific worth, as illustrated in examples (10-15).

Under environmental benefits, it was possible to distinguish between benefits to humans and the planet in general and benefits to wildlife in particular, as in:

(26) Trees benefit the planet by taking up carbon dioxide (Set 1/161). 
(27) they [trees] are wildlife habitats (Set 1/161)

The latter assuming the intrinsic value of wildlife.

Values to physical and mental health and wellbeing include appreciation of the healing effects of the natural environment and the existential benefit to be gained from contact with nature, which may be compromised in urban living as in:

(28) Trees are a refuge from modern stark life (Set 1/1)

In these references to health and wellbeing, the appreciation involves an expression of the positive affective impact of the trees on the story-teller, rather than the more detached evaluation of benefit, implicated in the other instrumental values.

Appreciation of the recreational value of trees refer mostly to children playing in the branches with some mention of gardening activities.

The socio-cultural values represented in the stories include appreciation of how trees and woodland establish connections to place and time, specifically, references to heritage, tradition and tourism, as eloquently expressed in:

(29) ...trees give a sense of place: each individual specimen and wood is specific to its location, whether a back garden, a village green, a city square, a field or a hillside, contributing to how, as humans, we locate ourselves in our communities and families...(Set 1/102).

Appreciation of the scientific-educational value of trees is rare and mostly implicit, as in:

(30) found this tree is in the Temple Garden. The tree is unusual in that it's a multi stemmed hemlock - typically grown in plantations with a straight single stem. (Set 2/168)

Finally, appreciation of trees as material resource mainly include references to the wood used in construction and heating, as in: 
The integrated classificatory framework, linking the values of nature with their attitudinal realizations, is summarised in Table 3, including explicit and implicit examples from the corpus. ${ }^{9}$

\section{[TABLE 3 ABOUT HERE]}

Once the values of nature were matched to their expressive categories in this way, it was possible to proceed with the third stage of the analysis, establishing how frequently each of the values was represented in the corpus. This stage is presented in section 6.3.

\subsection{Values in the Tree Narratives}

In most of the stories, a number of different values co-exist, sometimes within the same expression. Apart from the semantic and lexico-grammatical properties outlined in section 6.2 , context was crucial in a) distinguishing between categories and b) deciding on the overriding meaning in the case of overlap.

For example, 'The pleasure of the dappled sunlight on a summers day' (Set 1/7) in the context of further two prevalently aesthetic descriptions in the same story (i.e. 'The colours and beauty of autumn ... The starkness of the branches against the deep blue of a winter sky') was classified as Aesthetic Engagement, whilst 'Trees are a huge source of pleasure for me' (Set 1/124) in the context in which the story-teller also states that 'I have loved them ever since I was a child', was classified as Affective Impact.

Similarly, although 'I have loved them ever since I was a child' refers to memory, its overriding meaning in context is Affective Impact. Conversely, 'When I was a child, I

\footnotetext{
${ }^{9}$ In distinguishing between explicit and implicit formulations, I take a slightly wider view of explicitness than in Martin and White (2005), including not only straight attribution (e.g. trees are beneficial to the planet) but also explicit evaluative representations such as Trees benefit the planet by taking up carbon dioxide (Set 1/161)
} 
remember a wonderful Oak tree' (Set 1/80) appearing before 'That was 63 years ago, I hope it's still there' was classified as Memory.

Finally, it did not seem relevant, for the sake of this study, to count the occurrences of explicit and implicit evaluations separately. The findings (summarised in Table 4) show that the most represented value is Affective Impact with 312 (17.38\%) occurrences. Considering

\section{[TABLE 4 ABOUT HERE]}

that a degree of affective impact is also involved in the references to Memories (187/10.41\%), Sensorial Experience (189/10.52\%) and Aesthetic Engagement (114/6.35\%), overall emotive engagement is represented in 802 instances, amounting to over $44 \%$ of all instances.

Appreciation for the Scenic Beauty of woodland (at almost 5\%) figures slightly less frequently than Aesthetic Engagement.

Finally, references to the Intrinsic objective value of woodland also figure very frequently with 187 instances (nearly 11\%).

The intrinsic values (objective and subjective) of woodland are, overall, more represented (nearly $60 \%$ of all instances) than the instrumental ones (nearly $40 \%$ of all instances). Most of the references to the latter focus on Health/Wellbeing and Environmental benefits (210 instances/just over $11 \%$ and 193 instances/ just under 11\%, respectively). However, expressions that refer to the mental or even spiritual wellbeing to be derived from being in woodland are, arguably, more affective than instrumental in nature and reminiscent of Sensorial Experience.

It is also noticeable that, out of the overall references to Environmental benefits, over half concern benefits to Wildlife rather than Humans. The references to wildlife are 
particularly relevant as they assume its intrinsic objective value. If added to the appreciation for the intrinsic objective value of woodland (nearly $11 \%$ ), the intrinsic objective value of nature figures very prominently in the stories, amounting to $17 \%$ of all instances.

Also reasonably well-represented, is the Socio-cultural/ historical value of woodland (101 instances/ nearly 6\%), which although instrumental, retains a strong affective component.

The Recreational benefits afforded by trees (particularly climbing) are mentioned relatively often (152 instances/ over $8 \%$ ). When connected to memories and represented as immersive experiences, these references also entail emotive involvement.

Little mention is made of trees as natural Resource with only 52 instances (nearly $3 \%$ ) and hardly any reference to their Scientific-educational value (10 instances/ $0.55 \%$ ).

\section{Discussion}

This analysis has illustrated how the critical insight that may be achieved through discourse analysis may be maximised by integrating extralinguistic with linguistic analytical categories. In traditional critical discourse approaches, linguistic analysis is applied directly to the 'text', leading to a critical appreciation of how particular expressive choices underlie particular (socio-political) perspectives in in the context under examination. This is illustrated in Diagram 1.

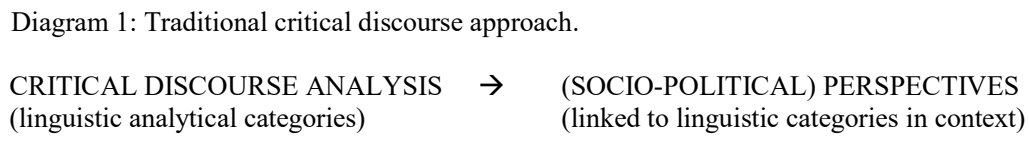

This analytical direction applies to this study to the extent that the story tellers' overriding positive attitude to trees and woodland may be clearly retrieved from their explicit and implicit expressions of positive evaluation. What the analysis was particularly concerned 
with, however, was illustrating how the analytical categories may, themselves, be informed by a critical appreciation of the wider ideological potential arising from the evaluation of trees and woodland, namely values of nature. The Appraisal analytical categories were informed by this ideological potential whilst, at the same time, they were used to refine the ideological distinctions expressed in the narratives. Ultimately, this approach highlighted not only the story tellers' positive attitude to woodland (to be expected) but also the range of positive human experiences that underlie such attitude - namely affective and immersive experiences - and the applicable set of values ascribed to woodland. This layered critical approach is illustrated in Diagram 2.

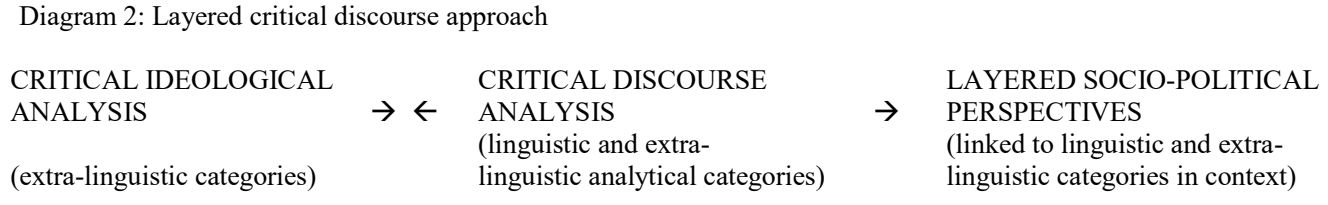

By giving priority to extralinguistic pragmatic rather than semantic and lexicogrammatical categories, furthermore, it is possible to avoid the 'Russian Doll' conundrum of distinguishing between layers of implications that blur the distinctions between AFFECT, APPRECIATON and JUDGEMENT (Thompson, 2014). This approach, where possible, enables the researcher to capture evaluation at a more dynamic, global and functional level than in the traditional Appraisal applications, whilst still providing clear justification for the categorization of the material.

The findings may also be used to critically appraise, firstly, how the content of the narratives was used for the aim they were initially collected for (contributing to the drafting of the Charter) and, secondly, with reference to wider implications for environmental policies. This is discussed in the rest of this section. 
The narratives clearly convey the story-tellers' strong positive evaluation of trees and woodland, providing a strong basis for WT to build their call to action (protection of trees and woodland) in the Charter. This includes the directives expressed under the 10 main Principles ${ }^{10}$ and the more detailed actions listed under each Principle. The values expressed in the narratives are mostly echoed in the Charter, albeit with a different emphasis, namely an overall bias towards instrumental over intrinsic objective/ subjective values, as follows: The environmental value of woodland to humans is explicitly called to bear on Principle 10 (planting trees to stave off flooding, strengthen waterways and support farming). The sociocultural/historical value of woodland is the explicit focus of Principles 5 (historical, heritage value), 6 (maintenance of socio-cultural character of local spaces) and 8 (social inclusion, with brief mention of recreational opportunities). Principle 4 is about maximising the resource value of trees, whilst Principle 7 refers to the health and wellbeing benefits of woodland, including brief mention of sensorial experiences. Principle 9 only includes directives as to combating environmental threats (pests, diseases etc) to woodland.

The intrinsic objective and subjective values (Essential Worth, Affective impact, Memory, Aesthetic Engagement/Appreciation) represented in the stories are appealed to more indirectly throughout the Principles, particularly within Principle 2 . Principle 1 assumes the intrinsic value of wildlife. Principle 3 stands out for its focus on a value that was only indirectly represented in the stories - specifically in the stories that take the form of poetry (two in all) or have a poetic tone - namely the value to inspire creative work (painting, poetry, writing and arts in general). This inspirational value is acknowledged by de Groot and Ramakrishnan (2005, pp. 457-474) in their overview of 'cultural services and amenities' (see

\footnotetext{
101 . Sustain landscapes rich in wildlife, 2. Plant for the future, 3. Celebrate the power of trees to inspire, 4. Grow forests of opportunity and innovation, 5. Protect irreplaceable trees and woods, 6. Plan greener local landscapes, 7. Recover health, hope and wellbeing with the help of trees, 8. Make trees accessible to all, 9. Combat the threats to our habitats and 10. Strengthen our landscapes with trees
} 
section 3) and it, arguably, assumes a deep affective connection between people and woodland.

Under Principle 8, moreover, reference is made to the importance of 'fostering a love for trees and woods across society' that will ensure that 'people across the UK will stand up for them'. The stories are testimony to this as it is clear that the story-tellers, all members of WT, endorse the work of this organization because they have a strong appreciation of the intrinsic value of woodland, in its own right, and of the affective and life-enhancing relationship between people and woodland.

I would, therefore, argue that the WT stories provide not only a powerful basis for a call to action (as presented in the Charter) but also a valuable insight into the nature of the deep connection that people may feel for woodland (or nature in general) and of how it is established. This, in turn, increases our understanding of how this connection may be fostered among groups of people who do not experience it. According to many environmentalists, it is this connection that is, ultimately the crucial motivation behind preservation initiatives. Fisher, for example, claims that:

attempts to justify preservation based solely on the instrumental value of nature need to be supplemented by some notion of nature's intrinsic value. Merely appealing to the ways that humans are dependent on nature will not provide sufficient reason to preserve nature in an undeveloped state. This dependence might convince us to conserve water, to restrain the use of toxic pesticides, to not drive fish species to extinction, and to limit excessive air pollution. But all of this falls far short of preserving nature as WILDERNESS or returning her to a pristine state (Fisher 2003, p. 265).

Similarly, Sandler (2012, p. 4) maintains that, with respect to justifying conservations goals, instrumental values may be useful but are, ultimately, 'replaceable and compensatable', 
whereas intrinsic value provide 'more stable and robust' motivation. Intrinsic values, including the essential worth of all living things, are explicitly foregrounded in some environmental agenda-setting documents such as the Earth Charter ${ }^{11}$. Both Cooper (2016, p. 222) and Fisher (2003) refer to the concept of aesthetic preservationism, which they see as the feelings of duty, love, care and respect that may be derived from deep aesthetic appreciation of nature. In their analysis of the interpretative brochures made available to tourists in the Vermont Forest, Derrien and Stokowsky (2017, p. 284) find that their value lies particularly in inspiring empathy for the forests and their habitat, which, in their opinion, is, ultimately, more conducive to forest preservation than the provision of educational information (which is, officially, the main purpose of such brochures).

It would seem crucial, therefore, that, alongside the publication of agenda-setting guidelines, such as the Charter, WT or similar organizations continue to develop initiatives aimed at increasing people's affective connection with woodland and appreciation of its essential worth. Some of the initiatives advocated in the Charter already reflect this realization, particularly the call to increase access to woodland for everyone (Principle 8) and to create opportunities for everyone to work and live in close vicinity of trees and green spaces and to be involved in decisions about tree planting and the planting itself (Principles 6 and 8). However, it is clear that the story tellers' deep connection with woodland results from more immersive experiences than these, including powerful emotional involvement with nature from their childhood, extended opportunities to enjoy life outdoors, including meaningful physical/ sensorial, aesthetic and spiritual experiences. Some research suggests that these are the experiences that (re-)connect us to our 'biophilic' side - the part of us that naturally loves nature (Futerra, 2015). There is, therefore, room for developing people's

\footnotetext{
${ }^{11}$ The Earth Charter was created by the independent Earth Charter Commission, which was convened as a follow-up to the 1992 Earth Summit in order to produce a global consensus statement of values and principles for a sustainable future. The document was developed over nearly a decade through an extensive process of international consultation, to which over five thousand people contributed. The Charter has been formally endorsed by thousands of organizations, including UNESCO and the IUCN (World Conservation Union). For more information, see www.EarthCharter.org
} 
opportunities to build longer-standing and deeper emotional connections with woodland and nature over time than those afforded by occasionally planting a tree or paying one or two educational visits to the countryside.

\section{Conclusion}

This article has demonstrated how a layered critical discourse approach may be used to identify a number of evaluative perspectives. The approach was informed by the initial critical appreciation of the contemporary philosophical and environmental policy values that reflect and shape our understanding of the values of nature. These values have provided the superordinate extralinguistic categories to build the analytical framework. The categorisation of the values represented in the stories was then achieved through the mediation of the Appraisal attitudinal options. Differently from previous applications of the Appraisal system, therefore, the values were not identified by the Appraisal categories themselves (AFFECT, APPRECIATON and JUDGEMENT). These semantic distinctions were used, instead, to differentiate with more precision between the values attributed to trees and woodland in the stories. Through this layered analysis, it was possible to observe the link between the story tellers' positive appreciation of nature (woodland), the values of nature on which such appreciation relies and the experiences that underlie both the values and the appreciation. This approach may be fruitfully employed to reveal the values underlying other environmentally relevant discourse or other discourse for which a set of potential extralinguistic evaluative criteria (political, cultural and social) may be identified and explored.

Moreover, the analysis has provided a critical insight into why people who support a charitable environmental organization, such as WT, feel strongly about nature and its conservation, highlighting the importance and origin of their affective relationship with the natural world. The implications of the findings were discussed with reference to their 
embedding in the Charter and other institutional initiatives, aiming to increase people's positive attitudes and conservation activities. Ultimately, the study confirms the benefits of exploring the values of nature through a discourse-based 'revealed preference' methodology and introduces a new critical approach to the study of evaluation that may be used for this purpose.

\section{References}

Bateman I.J., Mace G. M., Fezzi C., Atkinson, G. and Turner, K. (2011). Economic analysis for ecosystem service assessments. Environmental Resource Economics, 48(2),177218.

Berleant, A. (2013). What is aesthetics engagement? Contemporary Aesthetics, 11.

Bieling, C. (2016). Cultural ecosystem services as revealed through short stories from residents of the Swabian Alb (Germany). Ecosystem Services, 8, 207-215.

Buijs, A. E., Arts, B. J. M., Elands, B. H. M. and Lengkeek, J. (2011). Beyond environmental frames: the social representation and cultural resonance of nature in conflicts over a Dutch woodland. Geoforum, 42, 329-341.

Callicott, B. (1989). In defense of the land Ethic: Essays in environmental philosophy. Albany, NY: State University Press of New York.

Carlson, A. (2010). Environmental aesthetics and the requirements of environmentalism. Environmental Values, 19(3), 289-314.

Cooper, N. (2019). Examining evidence of how a culture values nature, particularly its spiritual value. In W. Filho and A. Consorte McCrea (Eds.). Sustainability and the humanities (pp. 239-266). Springer International Publishing AG, part of Springer Nature.

Cooper, N, Brady, E., Steen, H. and Bryce, R. (2016). Aesthetic and spiritual values of 
ecosystems: Recognizing the ontological and axiological plurality of cultural ecosystem 'services'. Ecosystem Services, 21, 218-229.

de Groot, R. and Ramakrishnan, P. (2005). Cultural and amenity services. Millennium Ecosystem Assessment (Vol. 1: Current state \& trends. pp. 457-474).

Derrien, M. and Stokowski, P. (2017). Discourses of place: environmental interpretation about Vermont Forests. Environmental Communication, 11(2), 276-287.

European Environment Agency (2013). Towards a common international classification of ecosystem services, CICES version 4.3. Available at: http://cices.eu

Elliot, R. (1992). Intrinsic value, environmental obligation and naturalness. The Monist, $75,138-160$.

Fisher, J. (2003). Aesthetics. In D. Jamieson (Ed.) A Companion to environmental philosophy (pp. 264-276). Malden MA: Blackwell.

Futerra (2015). Branding biodiversity. The new nature message. Futerra sustainability communications. Available at: https://www.wearefuterra.com/wpcontent/uploads/2015/10/Branding_Biodiversity.pdf

Halliday, M. A. K. and Matthiesen, C. (2004). An introduction to Functional Grammar (3rd ed.). London: Edward Arnold.

Hunston, S. and Thompson, G, (Eds.). (1999). Evaluation in text. Authorial stance and the construction of discourse. Oxford: Oxford University Press.

Irvine, K. N, O’Brien, L., Ravenscroft, N., Cooper, N. Everard, M., Fazey, I., Reed, M. S. and Kenteri, J. O. (2016). Ecosystem services and the idea of shared values. Ecosystem Services 21, 184-193.

Katz, E. (1992). The call of the wild. Environmental Ethics, 14, 265-273.

Kenter, J., Jobstvogt, N., Watson, V. Irvine, K. N., Christie, M. and Bryce, R. 
(2016). The impact of information, value-deliberation and group-based decision making on values for ecosystem services: Integrating deliberative monetary valuation and storytelling. Ecosystem Services, 21, 270-290.

Martin, J. and White, P. (2005). The language of evaluation. Palgrave Macmillan UK.

Read, R. and Scott Cato, M. (2014). A price for everything?: The natural capital controversy. Journal of Human Rights and the Environment, 5(2), 153-167.

Rolston, H. (1986). Philosophy gone wild: Essays in environmental ethics. Amherst, NY: Prometheus.

Sandler, R. (2012). Intrinsic value, ecology and conservation. Nature Education Knowledge, $3(10), 4$.

Sterba, J. (2001). Three challenges to ethics: Environmentalism, feminism and multiculturalism. Oxford, UK: Oxford University Press.

Stibbe, A. (2015). Ecolinguistics. Language, ecology and the stories we live by ( $\left.1^{\text {st }} \mathrm{ed}.\right)$. London: Routledge.

Taylor, P. (1986). Respect for nature: A theory of environmental ethics. Princetown, NJ: Princetown University Press.

Thompson, G. and Alba-Juez, L. (Eds). (2014). Evaluation in context. Amsterdam: Benjamins.

Thomson, G. (2014). Affect and emotion, target-value mismatches and Russian dolls. In G. Thompson and L. Alba-Juez (Eds). Evaluation in context (pp. 47-66). Amsterdam: Benjamins.

Turnpenny, J. and Russel, D. (2017). The idea(s) of 'valuing nature': Insights from the UK's ecosystem services framework. Environmental Politics, 26(6), 973-993. 


\section{Acknowledgement}

This research has been conducted under the auspices of Woodland Trust and I would like to thank them for their support and essential contribution to this study in (i) supplying the data for analysis, (ii) clarifying the context in which it was collected and (iii) their willingness for the findings to be disseminated at their national events and through their publications. I am also extremely grateful to the WT members who supplied the stories in the first place and were willing for the data to be analysed and used to support WT's environmental agenda.

\section{Tables}

Table 1. Categories of APPRECIATION within the Appraisal model (Martin and White, 2005, p. 56), showing positive examples only.

\begin{tabular}{|c|c|}
\hline $\begin{array}{l}\text { REACTION: } \\
\text { IMPACT: 'did it grab me?' }\end{array}$ & $\begin{array}{l}\text { arresting, captivating, engaging...; fascinating, exciting, moving... lively, dramatic, intense... } \\
\text { remarkable, notable, sensational... }\end{array}$ \\
\hline 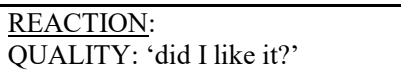 & okay, fine, good.... lovely, beautiful, splendid... appealing, enchanting, welcome... \\
\hline $\begin{array}{l}\text { COMPOSITION: } \\
\text { BALANCE 'did it hang together?' }\end{array}$ & $\begin{array}{l}\text { balanced, harmonious, unified... symmetrical, proportioned... consistent, considered, logical... } \\
\text { shapely, curvaceous, willowy... }\end{array}$ \\
\hline $\begin{array}{l}\text { COMPOSITION: } \\
\text { COMPLEXITY: } \\
\text { 'was it hard to follow?' }\end{array}$ & simple, pure, elegant... lucid, clear, precise... intricate, rich, detailed... \\
\hline $\begin{array}{l}\text { VALUATION: } \\
\text { 'was it worthwhile?' }\end{array}$ & $\begin{array}{l}\text { penetrating, profound, deep... innovative, original, creative... timely, long awaited, landmark, } \\
\text { inimitable, exceptional, unique... authentic, real, genuine... valuable, priceless, worthwhile... } \\
\text { appropriate, helpful, effective... }\end{array}$ \\
\hline
\end{tabular}

Table 2: The system of JUDGEMENT (adapted from Martin and White, 2005, p. 53) only showing positive examples, potentially relevant to trees

\begin{tabular}{|l|l|}
\hline Social Esteem & positive [admire] \\
\hline $\begin{array}{l}\text { normality } \\
\text { 'how special?' }\end{array}$ & normal, natural, familiar, stable, predictable... \\
\hline $\begin{array}{l}\text { capacity } \\
\text { 'how capable?' }\end{array}$ & powerful, vigorous, robust, healthy, productive... \\
\hline $\begin{array}{l}\text { tenacity (resolve) } \\
\text { 'how dependable?' }\end{array}$ & plucky, brave, heroic, reliable, dependable, loyal, flexible, adaptable \\
\hline
\end{tabular}

\begin{tabular}{|l|l|}
\hline Social Sanction & positive [praise] \\
\hline $\begin{array}{l}\text { veracity (truth) } \\
\text { 'how honest?' }\end{array}$ & honest, truthful, credible \\
\hline $\begin{array}{l}\text { propriety (ethics) } \\
\text { 'how far beyond } \\
\text { reproach?' }\end{array}$ & good, moral, caring, sensitive, kind, modest, humble, generous \\
\hline
\end{tabular}


Table 3. Values, attitudinal categories and examples

\begin{tabular}{|c|c|c|c|}
\hline VALUES & Attitude & Examples (explicit) & Examples (implicit) \\
\hline $\begin{array}{l}\text { Intrinsic (objective) } \\
\text { Trees have their own } \\
\text { essential worth as living } \\
\text { entities, as essential part } \\
\text { of nature (not related to } \\
\text { human benefit) }\end{array}$ & $\begin{array}{l}\text { APPRECIATION: } \\
\text { Valuation (important, } \\
\text { priceless, inimitable, } \\
\text { exceptional, unique) } \\
\text { JUDGEMENT: } \\
\text { Capacity (powerful, } \\
\text { vigorous); Tenacity } \\
\text { (brave); Propriety (kind, } \\
\text { humble) }\end{array}$ & $\begin{array}{l}\text { Woods are precious! (Set } \\
3 / 48) \\
\\
\text {...they bravely stand } \\
\text { there (Set } 3 / 86)\end{array}$ & $\begin{array}{l}\text { Without trees the world } \\
\text { will lose one of its } \\
\text { dimensions (Set } 1 / 1) \text {. } \\
\text { The tree seems to like } \\
\text { being hugged and talked to } \\
\text { (Set } 3 / 5) \\
\text { It amazed me the strength } \\
\text { of that branch a testament } \\
\text { of a trees ability to } \\
\text { weather any storm (Set } \\
\text { 2/82) }\end{array}$ \\
\hline $\begin{array}{l}\text { Intrinsic (subjective) } \\
\text { Trees are valued } \\
\text { intrinsically for their } \\
\text { affective impact (emotive/ } \\
\text { spiritual) }\end{array}$ & $\begin{array}{l} \\
\text { APPRECIATION: } \\
\text { Emotive impact }\end{array}$ & $\begin{array}{l}\text { I have always loved trees } \\
\text { and woodland. (Set } \\
3 / 169) \\
\text { the loss of the Silence } \\
\text { Tree, ... makes me feel } \\
\text { sad, (Set 2/39) } \\
\text { the oak pictured was } \\
\text { truly amazing. (Set 2/27) }\end{array}$ & $\begin{array}{l}\text { sometimes I stare at them } \\
\text { in wonder (Set 1/30) } \\
\text { my dad took my brother } \\
\text { and me to the major oak. } \\
\text { We went inside it... it was } \\
\text { wonderful. (Set } 2 / 14)\end{array}$ \\
\hline $\begin{array}{l}\text { Intrinsic (subjective) } \\
\text { Trees are valued } \\
\text { intrinsically for evoking } \\
\text { (positive) memories }\end{array}$ & $\begin{array}{l}\text { AFFECT: } \\
\text { Memory }\end{array}$ & $\begin{array}{l}\text { Reminds me of my } \\
\text { childhood as a small } \\
\text { boy... (Set } 1 / 143)\end{array}$ & $\begin{array}{l}\text { Planted a few where I lived } \\
\text { in also in memory of } \\
\text { husband, celebrating } \\
\text { births of grandchildren. } \\
\text { (Set } 1 / 146)\end{array}$ \\
\hline $\begin{array}{l}\text { Intrinsic (subjective) } \\
\text { Trees are valued } \\
\text { intrinsically for the } \\
\text { sensorial experience } \\
\text { (sight, touch, smell, } \\
\text { hearing, taste) they afford }\end{array}$ & $\begin{array}{l}\text { APPRECIATION: } \\
\text { Sensorial }\end{array}$ & $\begin{array}{l}\text { All trees smell good }(\text { Set } \\
1 / 37)\end{array}$ & $\begin{array}{l}\text { The sound of the leaves in } \\
\text { the wind, the shade, the } \\
\text { feel of the bark, the smell } \\
\text { of the leaves (Set 1/1) }\end{array}$ \\
\hline $\begin{array}{l}\text { Intrinsic (subjective) } \\
\text { Trees' are valued } \\
\text { intrinsically for the } \\
\text { aesthetic engagement they } \\
\text { afford }\end{array}$ & $\begin{array}{l}\text { APPRECIATION: } \\
\text { Aesthetic impact }\end{array}$ & $\begin{array}{l}\text { Trees possess a majestic } \\
\text { beauty (Set } 1 / 31)\end{array}$ & $\begin{array}{l}\text { I love the dark winter in all } \\
\text { circumstance - Sheer } \\
\text { beauty (Set } 2 / 161)\end{array}$ \\
\hline $\begin{array}{l}\text { Intrinsic (subjective) } \\
\text { Trees are valued } \\
\text { intrinsically for their } \\
\text { beauty (scenic) }\end{array}$ & $\begin{array}{l}\text { APPRECIATION: } \\
\text { Aesthetic }\end{array}$ & $\begin{array}{l}\text { They look great in } \\
\text { Autumn colours and the } \\
\text { winter snow for great } \\
\text { photos (Set } 2 / 53 \text { ). }\end{array}$ & $\begin{array}{l}\text {... a small cherry tree in my } \\
\text { garden which gave me } \\
\text { some... brilliant colour and } \\
\text { glamour to my garden } \\
\text { during spring (Set } 1 / 149 \text { ) }\end{array}$ \\
\hline $\begin{array}{l}\text { Instrumental } \\
\text { Trees are valued for their } \\
\text { environmental } \\
\text { significance to wildlife or } \\
\text { other nature }\end{array}$ & $\begin{array}{l}\text { APPRECIATION: } \\
\text { Valuation }\end{array}$ & $\begin{array}{l}\text { Trees are important for } \\
\text { wildlife [Set } 1 / 13] \\
\text { Trees are the } \\
\text { fundamental guardians } \\
\text { of all eco-systems (Set } \\
2 / 22)\end{array}$ & $\begin{array}{l}\text { It [the service tree] is a } \\
\text { fantastic habitat tree, } \\
\text { favoured by the mistle } \\
\text { thrush and host to several } \\
\text { species of leafminer moth } \\
\text { (Set } 2 / 112 \text { ) }\end{array}$ \\
\hline $\begin{array}{l}\text { Instrumental } \\
\text { Trees are valued for their } \\
\text { environmental } \\
\text { significance to humans }\end{array}$ & $\begin{array}{l}\text { APPRECIATION: } \\
\text { Valuation }\end{array}$ & $\begin{array}{l}\text { Trees benefit the planet } \\
\text { by taking up carbon } \\
\text { dioxide (Set 1/161) }\end{array}$ & $\begin{array}{l}\text { They are our lungs in a } \\
\text { world of increasing } \\
\text { pollution. They provide } \\
\text { shelter and shade and } \\
\text { reduce flooding (Set } 1 / 14)\end{array}$ \\
\hline Instrumental & $\begin{array}{l}\text { APPRECIATION: } \\
\text { Emotive impact }\end{array}$ & $\begin{array}{l}\text { There is nothing so } \\
\text { calming and restorative }\end{array}$ & $\begin{array}{l}\text { Trees give me stability in } \\
\text { this rapid-changing world } \\
\text { (Set } 1 / 53)\end{array}$ \\
\hline
\end{tabular}




\begin{tabular}{|c|c|c|c|}
\hline $\begin{array}{l}\text { Trees are valued for their } \\
\text { contribution to wellbeing } \\
\text { and health }\end{array}$ & & $\begin{array}{l}\text { as a deciduous woodland } \\
\text { (Set } 1 / 74 \text { ) }\end{array}$ & \\
\hline $\begin{array}{l}\text { Instrumental } \\
\text { Trees are valued for their } \\
\text { contribution to } \\
\text { recreational activities }\end{array}$ & $\begin{array}{l}\text { APPRECIATION: } \\
\text { Valuation }\end{array}$ & $\begin{array}{l}\text {... are fun to play in (Set } \\
1 / 48)\end{array}$ & $\begin{array}{l}\text {..provide diverse outdoor } \\
\text { opportunities (Set } 1 / 158 \text { ) }\end{array}$ \\
\hline $\begin{array}{l}\text { Instrumental } \\
\text { Trees are valued for their } \\
\text { historical/ cultural/ social } \\
\text { significance }\end{array}$ & $\begin{array}{l}\text { APPRECIATION: } \\
\text { Valuation }\end{array}$ & $\begin{array}{l}\text { a bluebell wood is } \\
\text { quintessentially British } \\
\text { (Set 1/97) }\end{array}$ & $\begin{array}{l}\text { Ancient woodland like } \\
\text { ancient monuments can } \\
\text { never be replaced (Set } \\
1 / 121 \text { ) }\end{array}$ \\
\hline $\begin{array}{l}\text { Instrumental } \\
\text { Trees are valued for their } \\
\text { scientific/ educational } \\
\text { significance }\end{array}$ & $\begin{array}{l}\text { APPRECIATION: } \\
\text { Valuation }\end{array}$ & $\begin{array}{l}\text { invaluable teaching } \\
\text { resource (Set } 1 / 96)\end{array}$ & $\begin{array}{l}\text { It } \text { [the wild service tree] is } \\
\text { an ancient woodland } \\
\text { indicator species... (Set } \\
3 / 112 \text { ) }\end{array}$ \\
\hline $\begin{array}{l}\text { Instrumental } \\
\text { Trees are valued as tools } \\
\text { or as natural resource }\end{array}$ & $\begin{array}{l}\text { APPRECIATION: } \\
\text { Valuation }\end{array}$ & $\begin{array}{l}\text { Material for } \\
\text { construction, furniture, } \\
\text { ideal non-toxic } \\
\text { alternative to plastic (Set } \\
3 / 43 \text { ) }\end{array}$ & $\begin{array}{l}\text { They provide beautiful } \\
\text { furniture (Set } 1 / 55 \text { ) } \\
\text { Trees provide timber to } \\
\text { build and furnish our } \\
\text { homes (Set } 3 / 13 \text { ) }\end{array}$ \\
\hline
\end{tabular}

Table 4. Showing frequency of values in the corpus (all three sets)

\begin{tabular}{|l|l|l|}
\hline VALUES & Occurrences & \% \\
\hline $\begin{array}{l}\text { Intrinsic (objective) } \\
\text { Essential worth (not related to human benefit) }\end{array}$ & 187 & 10.41 \\
\hline $\begin{array}{l}\text { Intrinsic (subjective) } \\
\text { Trees are valued intrinsically for their affective impact (emotive/ spiritual) }\end{array}$ & 312 & 17.38 \\
\hline $\begin{array}{l}\text { Intrinsic (subjective) } \\
\text { Trees are valued intrinsically for evoking (positive) memories }\end{array}$ & 187 & 10.41 \\
\hline $\begin{array}{l}\text { Intrinsic (subjective) } \\
\text { Trees are valued intrinsically for the sensorial experience they afford }\end{array}$ & 189 & 10.52 \\
\hline $\begin{array}{l}\text { Intrinsic (subjective) } \\
\text { Trees are valued intrinsically for the aesthetic engagement they afford }\end{array}$ & 114 & 6.35 \\
\hline $\begin{array}{l}\text { Intrinsic (subjective) } \\
\text { Trees are valued intrinsically for their beauty (scenic) }\end{array}$ & 88 & 4.90 \\
\hline $\begin{array}{l}\text { Total intrinsic } \\
\text { Instrumental } \\
\text { Trees are valued for their environmental significance to wildlife/nature }\end{array}$ & 111 & 59.97 \\
\hline $\begin{array}{l}\text { Instrumental } \\
\text { Trees are valued for their environmental significance to humans }\end{array}$ & 82 & 6.18 \\
\hline $\begin{array}{l}\text { Instrumental } \\
\text { Trees are valued for their contribution to wellbeing and health }\end{array}$ & 210 & 4.56 \\
\hline $\begin{array}{l}\text { Instrumental } \\
\text { Trees are valued for their contribution to recreational activities }\end{array}$ & 152 & 11.6 \\
\hline $\begin{array}{l}\text { Instrumental } \\
\text { Trees are valued for their historical/ cultural/ social significance }\end{array}$ & 101 & 8.46 \\
\hline $\begin{array}{l}\text { Instrumental } \\
\text { Trees are valued for their scientific/ educational significance }\end{array}$ & 10 & 5.62 \\
\hline $\begin{array}{l}\text { Instrumental } \\
\text { Trees are valued as tools or as natural resource }\end{array}$ & 52 & 0.55 \\
\hline $\begin{array}{l}\text { Total instrumental } \\
\text { Total values expressed }\end{array}$ & 719 & 2.89 \\
\hline
\end{tabular}

